\title{
Learners and Teacher Toward The Problem-Solving Based Learning Media
}

\author{
Vitria Marsela ${ }^{1 *}$, Subadiyono ${ }^{2}$, Didi Suhendi ${ }^{3}$ \\ 1,2,3 Indonesian Language Education Study Program, Teacher and Training Faculty, Universitas Sriwijaya, Indonesia
}

\section{A R T I C L E I N F O}

Article history:

Received April 22, 2021

Revised April 24, 2021

Accepted September 22, 2021

Available online November 25, 2021

Kata Kunci:

Media Pembelajaran, Animasi,

Pemecahan Masalah

Keywords:

Learning Media, Animation,

Problem-Solving

DOI:

https://dx.doi.org/10.23887/jet.v5i4.3

3964

\begin{abstract}
A B S T RAK
Banyak peserta didik yang masih mengalami kesulitan dalam mengembangkan ide-ide mereka tentang teks eksplanasi saat menjalani proses pembelajaran di kelas. Penelitian ini bertujuan untuk menganalisis kebutuhan peserta didik dan guru terhadap pengembangan media pembelajaran berupa animasi menulis teks eksplanasi berbasis pemecahan masalah. Penelitian ini merupakan penelitian kualitatif yang menganalisis tahap pertama dan tahap desain penelitian dan pengembangan. Hal-hal yang dianalisis seperti kebutuhan peserta didik dan guru terhadap media pembelajaran animasi untuk menulis teks eksplanasi berbasis pemecahan masalah. Dari data yang dikumpulkan melalui angket dan wawancara terhadap 33 siswa kelas dan 1 guru bahasa Indonesia. Teknik yang digunakan untuk menganalisis data yiatu analisis deksriptif kualitatif dan kuantitatif. Hasil penelitian yaitu media pembelajaran animasi tentang penulisan teks eksplanasi berbasis pemecahan masalah dapat menjadi media yang inovatif untuk kegiatan pembelajaran dan dapat digunakan untuk mendukung kebutuhan peserta didik dan guru. Media pembelajaran ini bermanfaat bagi kedua belah pihak dan dapat diakses secara offline. Dengan demikian, media pembelajaran dapat menjadi alternatif bagi kebutuhan guru dan peserta didik dalam pembelajaran dan pengajaran menulis teks eksplanasi.
\end{abstract}

\section{A B S T R A C T}

Many students still have difficulty developing their ideas about explanatory texts while undergoing the learning process in class. This study aims to analyze the needs of students and teachers for the development of learning media in the form of animation writing explanatory texts based on problem-solving. This research is qualitative research that analyzes the first and design stages of research and development. The things that were analyzed were the needs of students and teachers for animated learning media to write problem-solving-based explanatory texts. From the data collected through questionnaires and interviews with 33 students and 1 Indonesian teacher. The technique used to analyze the data is descriptive qualitative and quantitative analysis. The research results show that animated learning media about problem-solving-based explanatory text writing can be an innovative medium for learning activities and can support students' and teachers' needs. This learning media is beneficial for both parties and can be accessed offline. Thus, learning media can be an alternative for the needs of teachers and students in learning and teaching writing explanatory texts.

This is an open access article under the CC BY-SA license. Copyright (C) 2021 by Author. Published by Universitas Pendidikan Ganesha.

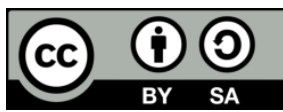

\section{INTRODUCTION}

Learning the Indonesian language should cover four language skills: listening, speaking, reading, and writing (Handhika et al., 2018; Saddhono et al., 2019; Sulistiyo, 2018). They should be based on the thinking skills, that cannot be separated, to support the language skills. During classroom learning, language skills should be integrated into one unity. However, for training purposes of language skills, each of them could be selected as the learning focuses (Khotimah et al., 2019; Yudhiantara \& Saehu, 2017). The writing is a communication activity in the form of written message delivery for other parties (Fleckenstein et al., 2020; Kim, 2021; Staples et al., 2013). Writing activities involve several elements, such as the writer as the message or writing messengers, the model or the written media, and the readers as the recipient (Masrur et al., 2020; Wong \& Russak, 2020). Writing skill refers to active-productive language skills. It is active since the writers actively write and productive because the writers produce writing texts. Writing is very important for education because it facilitates learners to think (Hill et al., 2020; Wong \& Russak, 2020). Writing has some benefits, such as (1) expressing the feelings (anxiety, restlessness, will, anger, etc), (2) instilling a strong understanding inside of the writers' brains, (3) to develop personal satisfaction, pride, feeling, and self-respect, (4) to improve the awareness 
and environmental sensitivity, (5) to participate, and (6) to develop a certain understanding and skills of using language (Flores, 2021; Yuniar et al., 2019). Writing activity is an intellectual activity because it is indicated with the skills to express the notion in delivering the message (Darmawan et al., 2017; Fu et al., 2019). Writing is a very useful activity for both writers and readers. Writing skill produces an excellent writing works, such as fiction or non-fiction. The skill is also useful for various activities and field participation (Abrams \& Byrd, 2016; Safura et al., 2017).

In this research, the analysis of need was done in writing explanatory texts. The text is an activity to develop the learners' creativity. This research was focused to describe the problems and the needs of the learners and the teachers in writing explanatory text at school. The chosen school was the Public Primary Junior High School 33 Palembang with its eighth-graders. The explanatory material had the purpose to allow learners to write explanatory texts based on the basic competence 4.10. It was to present information and data in the form of oral and written explanatory text by considering the structures and language features. The basic competence's expectation had not been in line with the actual condition. Many learners still had problems developing their ideas of explanatory text while having a classroom learning process. The solution to overcome this problem is to use learning media (Hanik, 2020; Maryanti \& Kurniawan, 2018). The learning media were audio-visual tools containing the learning materials, short videos, or movies in the forms of animations, and exercises (Liang et al., 2011; Michelsanti et al., 2019). Thus, the applied learning media should have been interesting for the learners so that they would be motivated to learn (Arimbawa et al., 2017; Xu \& Wu, 2021). The interesting and effective learning media could support the learners' understanding in receiving the delivered materials by the teacher. Therefore, it was important to find the learners' and teachers' needs (Michelsanti et al., 2019; Pattemore \& Muñoz, 2020).

There were similarities and differences between this research and the previous researches. The similarities were about the explanatory text materials while the differences dealt with the media, bases, and research subject selections. Previous research focused on applying the QUIP-based Nusantara local wisdom for explanatory text teaching materials (Sugianto, 2014). This research aims to analysis the learner and teacher need analysis toward the learning media development in the form of an animation for writing an explanatory text based on problem-solving for the eighth graders of Public JHS 33 Palembang. This research is expected to provide benefits both theoretically and practically. Theoretically, the results would be useful in understanding the concepts or theories. They would be also useful as literature and reference contribution in the research and development of animated learning media especially for explanatory writing activity with the problem-solving model. Practically, the results were expected to contribute to both teachers as the educational institutions and learners. Learners would be benefited from this research and development product because they could overcome any difficulties while writing explanatory text. Teachers would be benefited from this research product because the product could be the guideline and reference to teach the explanatory text. Thus, it would facilitate learners to carry out the learning activity. Besides that, this learning could improve the learners' skills in writing explanatory text.

\section{METHOD}

This research applied a qualitative approach to determine the learners' and teachers' needs. It meant this research was done in the planning stage of the Research and Development study. Therefore, it was in line with the current stage, the planning stage. The applied model had a function as the framework of this research. It was Allesi and Trollip's development model (2001). It was adapted, modified, and adjusted with the current needs of the research. Generally, the interactive multimedia development model has three attributes and three phases. Each attribute and phase consisted of various problems to be discussed. The attributes were t standards; ongoing evaluation; and project management. The development phases were planning, design, and development. The subjects consisted of the eighth-graders, 220 participants, of Public JHS 33 Palembang. However, the sample consisted of only 33 persons. It was based on the formula, 15\% of the whole population. This sampling was in line with Arikunto's survey model (2014). This research used questionnaires and interview to collect the data. The questionnaire was given to the learners while the interview was used for the teachers to obtain the initial information. Both data collecting techniques were used to determine the learners' and teachers' needs of the learning media development. The interview was used to clarify the questionnaire results. The researchers analyzed the questionnaire by tabulating, calculating, analyzing, interpreting, and describing the data into percentages. The results would be described as the initial identification of the developed learning media needs. The interview was analyzed objectively. Then, the results would be described and concluded. The conclusions would be used to complete the test data. They would be also used for developing and revising the developed learning media. 


\section{RESULT AND DISCUSSION}

\section{Result}

Based on the observation and interview results, it was found that the learners still had difficulties to produce or present an explanatory text in a complete written form. The activity was done by using the printed book provided by the government, titled Bahasa Indonesia Terbitan Kementerian Pendidikan dan Kebudayaan Republik Indonesia 2017 Kurikulum 2013. The teacher usually used the newspaper and the printed book as the reference for the material. The teacher admitted her learners had difficulties developing their ideas while writing the explanatory text. The other reason was writing the explanatory text was not interesting moreover when the learning media were only printed books and newspapers. The weaknesses of books and newspapers were less variety, monotonous, and not interesting. Thus, learners would be easily bored with the materials and they were lack learning motivation. The use of appropriate learning media could facilitate the teachers and learners to reach the objectives. Practically, she stated that the use of the computer-projected learning media was not maximum. The learning media in the form of problem-solving-based explanatory text with animation had not been used in the school. In learning the Indonesian language, the teacher used printed books, newspapers, whiteboards, and learning media so the learning was less varied. Learning media should be in line with the learners' characteristics. The teacher expected an interesting learning media development based on the learners' characteristics and needs.

Based on the need questionnaire of the learners, they needed learning media that could develop their ideas so they would be facilitated while writing the explanatory text. Learners also needed less boring, interesting, motivating, and encouraging learning media with complete materials. Unfortunately, they did not get those learning atmospheres at school. Based on the questionnaire of the learners' needs, they preferred interesting teaching and learning media. They also needed understandable media rather than only having lecturers. It was proven with a percentage of $90.9 \%$ that the learners preferred and needed the learning media. In a learning material especially about explanatory text writing, learners had difficulties connecting the ideas and the problems brought in the text. It was proven by a percentage of $96.5 \%$ of learners had difficulties. Therefore, there was a need for learning media in the form of problem-solving-based explanatory text writing in the form of animation. It was useful to facilitate the learners to write the explanatory text. It was proven from the questionnaire. A percentage of $97 \%$ of learners wanted to have a learning material to facilitate their writing learning. Learners wanted a specific learning media for writing explanatory text. It was proven with $96.9 \%$ of learners stated that the created learning media would be focused on writing explanatory text.

The learners also needed a learning media with complete materials. It was proven with a percentage of $97 \%$ of learners agreed with the learning media to be packaged completely. Based on the facts, the materials of the explanatory text materials consisted of the definition, the feature, the content of the text, the structure of the text, the principle of the text's language features, the stages to summarize the text, and the stages to write the text. It was proven with a percentage of $96.9 \%$ of learners needed the materials in the learning media. A percentage of $97 \%$ of learners also admitted that the learning media should have examples of explanatory texts. The examples should not be realized only in text forms. It was proven by the questionnaire results. The percentage of $96.4 \%$ of learners also needed the explanatory text examples. It was also proven with $97 \%$ of learners agreed with the notion. They argued that if the examples in the learning media should be combined with the explanatory text structure materials. They should be packaged in the form of animated videos with subtitles and based on the text structures. Thus, they would be more aware of the text's systematic structures.

The result of the questionnaire proved a percentage of $93.9 \%$ of learners stated that they needed the exercise part of the learning media to be presented. They needed them to understand the concepts and to write. They argued that they needed interview videos with animation videos about COVID-19. Then, a percentage of 93.9\% of learners agreed with the notion if the interview video would be packaged in the form of two-person animation. This animation showed the two persons having an interview about COVID-19. Then, the main ideas of COVID-19 should be put in the interview conversation. Learners needed exercise to find problems and to find the solution. It could be seen from a percentage of $97 \%$ learners. Then, they needed exercise to identify the text structures and find the specific terms in the explanatory text. It was proven with the questionnaire results. It showed a percentage of $81.8 \%$. Besides that, for the writing exercise and developing ideas, learners were asked to find and note each main idea from the text about COVID-19 with the animation of two persons having an interview. Each main idea they obtained should be developed into whole writing based on the given structure and the grammar. It was proven with a percentage of $90.8 \%$, based on the questionnaire of learners' need results.

\section{Discussion}

Based on the learners' and the teacher's needs, the researchers proposed a learning media in the form of audio-visual, realized into animation with materials about problem-solving based explanatory text writing materials. The learning media facilitated the learners to understand the materials and to develop the ideas (bin 
Abdul Samat \& Abdul Aziz, 2020; Imamah \& Susanti, 2021). Thus, the learners' writing skills could be improved and they would be more creative and critical. This media was facilitated by complete features and communicative language uses (Alamiyah et al., 2021; Madleňák, 2015). It contained interesting illustrations to listen to so that learners would be encouraged to learn autonomously (Friedman \& Friedman, 2013; Setiyani et al., 2020). This media contained learning materials, learning videos, and evaluative questions. Thus, learners could learn and check their understanding by working on the questions (Buchori et al., 2017; Narayan et al., 2019). Dealing with the conceptual and material understandings, the exercise questions were made into multiple choices. Thus, learners could select the answers, find their correctness, and obtain the scores. Besides that, there were essays for the learners to work on and to develop their ideas based on the problem-solving model (Hwang et al., 2012; Kua, 2018; Nuraziza \& Suwarma, 2018). The problem-solving model was a presentation method by giving problems as the discussion milestone to be analyzed and synthesized. It was as the effort to find the solutions or the answers done by the learners (Effendi \& Hendriyani, 2020; Nurlaily et al., 2019; Zaki et al., 2020).

The strength point of this media was on the text writing activity. It was presented with essay exercises in the form of audio-visual animation based on a problem-solving model. The learners were asked to find and note each obtained idea as the data to help them writing. The video animation was packaged similarly to television news. They discussed something so learners would be interested to listen and pay attention. The video was a two-person animation having an interview about COVID-19. The learners were asked to observe, find, and note each main idea about COVID-19 in the conversation. Then, the main ideas were chosen to be the main data for the learners' writing. They should pay attention to the structures and the features of the language. The applied animation also had written text animation to empower the theory. The text and the life-creature animations were made attractively and lively to facilitate learners developing their ideas. The media could make a joyful, motivating, interesting, and resolutive learning atmosphere so that learners could solve the problems in the learning materials (Antal et al., 2017; Leatherman \& Cleveland, 2020; Puspitarini \& Hanif, 2019). The learning had a purpose to create learners with excellent, accurate, and quick problem-solving skills (Andriyani \& Suniasih, 2021; Hwang et al., 2012). The problem-solving model was considered as the accurate learning model for the learners to solve problems (Astra et al., 2020; Partayasa, 2020). The strength point of this method was its audio and visual matters. They could be used in an offline manner, stored, and brought. They could be stored in CDs and other storage devices. The applied animation also had written text animation to empower the theory. The text and the life-creature animations were made attractively and lively to facilitate learners developing their ideas (Koning et al., 2019; Kühl, 2021).

\section{CONCLUSION}

The animated learning media about problem-solving based explanatory text writing could be an innovative media for learning activity and could be used to support the learners' and teachers' needs. This learning media was useful for both parties and accessible in an offline manner. It could be installed on a laptop, stored, and brought. Thus, the learning media could be the alternative for the teacher's and learners' needs in learning and teaching explanatory text writing.

\section{REFERENCES}

Abrams, Z. I., \& Byrd, D. R. (2016). The effects of pre-task planning on L2 writing: Mind-mapping and chronological sequencing in a 1st-year German class. System, 63. https://doi.org/10.1016/j.system.2016.08.011.

Alamiyah, S. S., Kusuma, A., Juwito, J., \& Tranggono, D. (2021). Pergeseran Model Pendampingan Penggunaan Media Digital oleh Orangtua pada Anak di Masa Pandemi COVID-19 Pendahuluan Pandemi COVID19 telah menyebabkan perubahan pada berbagai aspek kehidupan manusia. Untuk mengatasi dan mengurangi dampak resiko pandemi ,. JCommsci-Journal Of Media and Communication Science, 4(1), 5-12. https://doi.org/10.29303/jcommsci.v4i2.120.

Andriyani, N. L., \& Suniasih, N. W. (2021). Development Of Learning Videos Based On Problem-Solving Characteristics Of Animals And Their Habitats Contain in Science Subjects On 6th-Grade. Journal of Education, 5(1), 37-47. https://doi.org/10.23887/jet.v5i1.32314

Antal, H., Bunnell, H. T., McCahan, S. M., Pennington, C., Wysocki, T., \& Blake, K. V. (2017). A cognitive approach for design of a multimedia informed consent video and website in pediatric research. Journal of Biomedical Informatics, 66, 248-258. https://doi.org/10.1016/j.jbi.2017.01.011.

Arimbawa, Wiyasa, \& Manuaba. (2017). Pengaruh Model Problem Based Learning Berbantuan Media Audio Visual Terhadap Penguasaan Kompetensi Ips. Mimbar PGSD Undiksha, 5(2), 1-8. 
https://doi.org/10.23887/jjpgsd.v5i2.11000.

Astra, I. M., Raihanati, R., \& Mujayanah, N. (2020). Development of Electronic Module Using Creative Problem-Solving Model Equipped with Hots Problems on The Kinetic Theory of Gases Material. Jurnal Penelitian \& Pengembangan Pendidikan Fisika, 6(2), 181-194. https://doi.org/10.21009/1.06205.

bin Abdul Samat, M. S., \& Abdul Aziz, A. (2020). The Effectiveness of Multimedia Learning in Enhancing Reading Comprehension Among Indigenous Pupils. Arab World English Journal, 11(2), 290-302. https://doi.org/10.24093/awej/vol11no2.20.

Buchori, Rahmawati, S., \& Wardani, S. (2017). The Development of A Learning Media for Visualizing the Pancasila Values Based on Information and Communication Technology. Jurnal Cakrawala Pendidikan, 36(3), 502-521. https://doi.org/10.21831/cp.v36i3.12748.

Darmawan, D., Setiawati, P., Supriadie, D., \& Alinawati, M. (2017). Penggunaan Multimedia Pembelajaran Interaktif Untuk Meningkatkan Keterampilan Menulis English simple Sentences pada Mata Kuliah Basic Writing Di Stkip Garut. Pedagogia, 15(1), 109. https://doi.org/10.17509/pedagogia.v15i1.6576.

Effendi, H., \& Hendriyani, Y. (2020). The Conceptual and Hypothetical Model of Interactive Blended Problem Based Learning. JPI (Jurnal Pendidikan Indonesia), 8(2), 285. https://doi.org/10.23887/jpiundiksha.v8i2.24162.

Fleckenstein, J., Keller, S., Krüger, M., Tannenbaum, R. J., \& Köller, O. (2020). Linking TOEFL iBT® writing rubrics to CEFR levels: Cut scores and validity evidence from a standard setting study. Assessing Writing, 43. https://doi.org/10.1016/j.asw.2019.100420.

Flores, J. A. A. (2021). The semiotics of writing: How adult L2 learners with emergent literacy make meaning in assessment texts through writing. Journal of Second Language Writing, 51. https://doi.org/10.1016/j.jslw.2021.100793.

Friedman, L. W., \& Friedman, H. H. (2013). Using social media technologies to enhance online learning. Journal of Educators Online, 10(1). https://doi.org/10.9743/JEO.2013.1.5.

Fu, Q.-K., Lin, C.-J., Hwang, G.-J., \& Zhang, L. (2019). Impacts of a mind mapping-based contextual gaming approach on EFL students' writing performance, learning perceptions and generative uses in an English course. Computers \& Education, 137. https://doi.org/10.1016/j.compedu.2019.04.005.

Handhika, T., Zen, R. I. M., Lestari, D. P., \& Sari, I. (2018). Gesture recognition for Indonesian sign language (BISINDO). In Journal of Physics: Conference Series, 1028(1). https://iopscience.iop.org/article/10.1088/1742-6596/1028/1/012173/meta.

Hanik, E. U. (2020). Self directed learning berbasis literasi digital pada masa pandemi covid-19 di Madrasah $\begin{array}{lllll}\text { Ibtidaiyah. } & \text { ELEMENTARY: Islamic Teacher Journal, }\end{array}$ https://doi.org/10.21043/elementary.v8i1.7417.

Hill, C., Khoo, S., \& Hsieh, Y.-C. (2020). An investigation into the learning transfer of English for specific Academic Purposes (ESAP) writing skills of students in Singapore. Journal of English for Academic Purposes, 46. https://doi.org/10.1016/j.jeap.2020.100908.

Hwang, G. J., Wu, P. H., \& Chen, C. C. (2012). An online game approach for improving students' learning performance in web-based problem-solving activities. Computers and Education, 59(4), 1246-1256. https://doi.org/10.1016/j.compedu.2012.05.009.

Imamah, N., \& Susanti, L. Y. (2021). Development of Sigil-Based Additives and Addictive Substances Teaching Chart for Junior High School Students: Alternative Learning Resources During a Pandemic. INSECTA: Integrative Science Education and Teaching Activity Journal, 2(1), 15-30. https://doi.org/10.21154/insecta.v2i1.2464.

Khotimah, K., Widiati, U., Mustofa, M., \& Ubaidillah, M. F. (2019). Autonomous English learning: Teachers' and students' perceptions. Indonesian Journal of Applied Linguistics, 9(2). https://doi.org/10.17509/ijal.v9i2.20234.

Kim, S. (2021). Prepping for the TOEFL iBT Writing test, Gangnam style. Assessing Writing, 49. https://doi.org/10.1016/j.asw.2021.100544.

Koning, B. B. de, Marcus, N., Brucker, B., \& Ayres, P. (2019). Does observing hand actions in animations and static graphics differentially affect learning of hand-manipulative tasks? Computers \& Education, 41. https://doi.org/10.1016/j.compedu.2019.103636.

Kua, M. Y. (2018). Penerapan Real World Problem Solving menggunakan Setting Argumentasi untuk Meningkatkan Kemampuan Berpikir Kritis dalam Pembelajaran Fisika Siswa SMA. Jurnal Ilmiah Pendidikan Citra Bakti, 5(2), 93-102. https://doi.org/10.5281/zenodo.3402640.

Kühl, T. (2021). Prerequisite knowledge and time of testing in learning with animations and static pictures: Evidence for the expertise reversal effect. Learning and Instruction, 73. https://doi.org/10.1016/j.learninstruc.2021.101457.

Leatherman, J. L., \& Cleveland, L. M. (2020). Student exam performance in flipped classroom sections is 
similar to that in active learning sections, and satisfaction with the flipped classroom hinges on attitudes toward learning from videos. Journal of Biological Education, 54(3), 328-344. https://doi.org/10.1080/00219266.2019.1575266.

Liang, Y., Zheng, T., \& Wang, M. (2011). English audio-visual teaching mode and its teaching environment construction - Henan Institute of Science and Technology as the example. 2011 International Conference on Multimedia Technology, 3050-3053. https://doi.org/10.1109/ICMT.2011.6001924.

Madleňák, R. et al. (2015). Designing a Social Network to Support E-learning Activities at the Department of Communications, University of Žilina. Procedia - Social and Behavioral Sciences, 176, 103-110. https://doi.org/10.1016/j.sbspro.2015.01.449.

Maryanti, S., \& Kurniawan, D. T. (2018). Pengembangan Media Pembelajaran Video Animasi Stop Motion Untuk Pembelajaran Biologi Dengan Aplikasi Picpac. Jurnal BIOEDUIN : Program Studi Pendidikan Biologi, 8(1), 26-33. https://doi.org/10.15575/bioeduin.v8i1.2922.

Masrur, I., Irawati, E., \& Sulistyo, G. H. (2020). Integrating Writing Process with Quantum Learning Framework in English Language Teaching. Jurnal Pendidikan: Teori, Penelitian, Dan Pengembangan, 5(3). https://doi.org/10.17977/jptpp.v5i3.13262.

Michelsanti, D., Tan, Z.-H., Sigurdsson, S., \& Jensen, J. (2019). Deep-learning-based audio-visual speech enhancement in presence of Lombard effect. Speech Communication, 115. https://doi.org/10.1016/j.specom.2019.10.006.

Narayan, V., Herrington, J., \& Cochrane, T. (2019). Design principles for heutagogical learning: Implementing student-determined learning with mobile and social media tools. Australasian Journal of Educational Technology, 35(3), 86-101. https://doi.org/10.14742/ajet.3974.

Nuraziza, \& Suwarma. (2018). Menggali Keterampilan Creative Problem Solving yang dimiliki Peserta didik SMP melalui Pembelajaran IPA Berbasis STEM. Jurnal WAPFI (Wahana Pendidikan Fisika), 3(1), 5561. https://doi.org/10.17509/wapfi.v3i1.10941.

Nurlaily, V. A., Soegiyanto, H., \& Usodo, B. (2019). Elementary school teacher's obstacles in the implementation of problem-based learning model in mathematics learning. Journal on Mathematics Education, 10(2), 229-238. https://doi.org/10.22342/jme.10.2.5386.229-238.

Partayasa, W. (2020). Pengaruh Model Pembelajaran Creative Problem Solving (CPS) Berbantuan Video Pembelajaran Terhadap Kemampuan Pemecahan Masalah ditinjau dari Minat. JNPM (Jurnal Nasional Pendidikan Matematika), 4(1), 168. https://doi.org/10.33603/jnpm.v4i1.2644.

Pattemore, A., \& Muñoz, C. (2020). Learning L2 constructions from captioned audio-visual exposure: The effect of learner-related factors. System, 93. https://doi.org/10.1016/j.system.2020.102303.

Puspitarini, Y. D., \& Hanif, M. (2019). Using Learning Media to Increase Learning Motivation in Elementary School. Anatolian Journal of Education, 4(2), 53-60. https://doi.org/10.29333/aje.2019.426a.

Saddhono, K., Sudarsana, I. K., \& Iskandar, A. (2019). Implementation of Indonesian Language the learning Based on Information and Communication Technology in Improving Senior High School Students' Achievement in Surakarta. Journal of Physics: Conference Series, 1254(1). https://doi.org/10.1088/1742-6596/1254/1/012059.

Safura, S. S., Suhartiningsih, S., \& Yuliati, N. (2017). Peningkatan Keterampilan Menulis Puisi Bebas Dengan Pilihan Kata Yang Tepat Melalui Penerapan Strategi Writing in the Here and Now Berbantuan Media Gambar Pada Siswa Kelas VA SDN Patrang 01 Jember Tahun Pelajaran 2016/ 2017. Jurnal Edukasi. https://doi.org/10.19184/jukasi.v4i1.5090.

Setiyani, Putri, D. P., Ferdianto, F., \& Fauji, S. H. (2020). Designing a Digital Teaching Module Based on Mathematical Communication in Relation and Function. Journal on Mathematics Education, 11(2), 223-236. https://doi.org/10.22342/jme.11.2.7320.223-236.

Staples, S., Egbert, J., Biber, D., \& McClair, A. (2013). Formulaic sequences and EAP writing development: Lexical bundles in the TOEFL iBT writing section. Journal of English for Academic Purposes, 12(3). https://doi.org/10.1016/j.jeap.2013.05.002.

Sugianto. (2014). Pengembangan Bahan Ajar Menulis Teks Eksplanasi Bermuatan Kearifan Nusantara Berbasis Strategi Quip untuk Siswa Kelas VIII SMP/MTS. Jurnal Pendidikan Bahasa Pascasarjana Unisma, 1(8). http://riset.unisma.ac.id/index.php/NOSI/article/view/4380.

Sulistiyo, U. (2018). Factors Affecting English Language Learning in English as a Foreign Language (EFL) Context: A Literature Review Study. Indonesian Journal Of Educational Research, 3(1), $20-24$. https://doi.org/10.30631/ijer.v3i1.54.

Wong, K. S. R., \& Russak, S. (2020). Hong Kong Cantonese L1 preschool children's name writing in English L2. Cognitive Development, 56. https://doi.org/10.1016/j.cogdev.2020.100957.

$\mathrm{Xu}, \mathrm{X} .$, \& Wu, H. (2021). Audio-visual interactions enhance soundscape perception in China's protected areas. Urban Forestry \& Urban Greening, 61. https://doi.org/10.1016/j.ufug.2021.127090.

Yudhiantara, R. A., \& Saehu, A. (2017). Mobile-Assisted Language Learning (MALL) in Indonesian Islamic 
Higher Education. IJELTAL (Indonesian Journal of English Language Teaching and Applied Linguistics), 2(1), 21-31. https://doi.org/10.21093/ijeltal.v2i1.52.

Yuniar, R. F., Widiati, U., \& Astuti, U. P. (2019). The Effect of Using Wattpad on Process-Genre Approach towards Writing Achievement in Tertiary Level. Jurnal Pendidikan Teori, Penelitian, Dan Pengembangan, 4(7). https://doi.org/10.17977/jptpp.v4i7.12631.

Zaki, N. A. A., Zain, N. Z. M., Noor, N. A. Z. M., \& Hashim, H. (2020). Developing a conceptual model of learning analytics in serious games for stem education. Jurnal Pendidikan IPA Indonesia, 9(3), 330339. https://doi.org/10.15294/jpii.v9i3.24466. 